\title{
Effect of Partial or Total Inclusion of Betaine and/or Choline Instead of Added Methionine in Broiler Diets on: \\ 1- Growth Performance and Economic Efficiency. Sherif, Kh. El ${ }^{1}$; M. M. El- Shinnawy ${ }^{2}$; H. F. A. Motawe ${ }^{3}$ and M. A. Osman ${ }^{3}$ \\ ${ }^{1}$ Poult. Prod. Dept. Fac. Agric., Mansoura Univ. \\ ${ }^{2}$ Animal. Prod. Dept. Fac. Agric., Mansoura Univ. \\ ${ }^{3}$ Regional Center for Food and Feed, Agric. Res. Center, Cairo-Egypt.
}

\begin{abstract}
This investigation aimed to evaluate the effect of partial or total replacement of added DL-methionine (Met) with betaine or choline or both in diets of broilers chicks on growth performance and economic efficiency. A total numbers of 440 day-old straight- run Cobb500 broiler chicks were randomly taken, weighed and divided into eleven treatments (40 birds each). Each treatment contained 4 replicates of 10 birds. A basal diet was formulated as control according to NRC, recommendations for starter (0-12 days, $0.165 \%$ added Met.), grower (12-24 days, $0.135 \%$ added Met.) and finisher (24-36 days, $0.090 \%$ added Met.). Treatment one was fed the control ration while the other ten treatments were fed the control ration after partial or total replacement the added Met. with betaine or choline or both. The results of the present study indicated that replacement of added methionine with betaine and/or choline positively affected final live body weight (LBW) of broiler chicks compared with their control group. The highest LBW was achieved by chicks fed T10 (50\% betaine and 50\% choline) and T7 (100\% betaine) when compared with other dietary treatments while the lowest value was recorded with the control group. The same trend of response was observed in body weight gain (BWG) of chicks fed on diets containing different levels of betaine or choline during the whole experimental period compared with their control counterparts. Slight differences were observed among the different experimental groups of broiler chicks in feed intake FI which seemed erratic and perhaps were not related to the effect of dietary treatments. Replacing added dietary methionine with betaine and/or choline in broiler diets led to superior means of feed conversion ratio (FCR) during the three phases of growth and the whole experimental period to those attained by the control group. During the whole experimental period (0-36 days old), birds fed diets in which betaine completely replaced added methionine achieved the lowest PER compared with their control group and other treatments. Also this level of replacement resulted in significantly $(\mathrm{P}<0.05)$ the best EEU value (4.82) as compared to the control group (5.22). Inclusion of $100 \%$ betaine instead of added methionine showed significantly $(\mathrm{P}<0.05)$ higher PI value compared with the control group. Birds appeared health and total mortality rates throughout the experimental period were within the normal range among treatments. The lowest cost/kg body weight (11.96 LE) was observed with chicks fed diets completely replaced added methionine, while the highest value in which betaine (12.91 LE) was recorded with the control group. Similar results were observed with economic efficiency. It could be concluded that replacing methionine by betaine, choline or both improved body weight gain, feed conversion and economic efficiency of broiler production.
\end{abstract}

Keywords: Methionine; Betaine; Choline; Broiler chickens; Growth performance; Economic efficiency

\section{INTRODUCTION}

Feed additives are important materials that can improve the efficiency of utilization of dietary labile methyl (meth) groups. These compounds were proposed to be nutrients (McDevitt et al.; 2000). Methionine (Met.), choline, betaine (BET) and Folic acid are all considered as meth. donors to body metabolic reactions and have been shown to compensate for the partial deficiency of labile meth. groups in corn-soybean-based diets (Matthews and Southern; 2000). Modern nutrition has revealed that Met. is one of the most limiting amino acids that play a crucial role in body protein synthesis and therefore it would be beneficial to spare its function as a meth. donor. It has been shown that folic acid has to take meth. group before performing its rate as a meth. donor. Choline first has to be converted and then activated to betaine before methyl groups are liberated to fulfill methylation function (McKeever et al.; 1991). In contrast, BET contains three meth. groups in its structure and donates them in several metabolic reactions. On a molecular weight basis, BET contains about 3.75 times the meth. groups of Met. and therefore would be an effective compound to spare dietary Met as a methyl donor.

However, the Methionine sparing effect of BET has been the subject of some controversy. Some studies have shown positive responses of animals to BET supplementation in Methionine-deficient diets which included improved carcass characteristics and broiler performance (Gao et al.; 2006). These responses were obtained when one part of BET was supplemented to replace two parts of dietary DL-Met. However, the Met sparing effect of BET was not observed in other studies (EsteveGarcia and Mack; 2000). It seems that the efficiency of Met sparing effect of BET is associated with dietary compositions, animal physiological stage and living conditions.

Betaine is a naturally occurring amino acid derivative found in a variety of feedstuffs of animal origin and plant. Betaine has two primary metabolic roles: it is an osmolyte that assists in cellular water homeostasis and it is a methyl group donor (Petronine et al.; 1992).

BET, choline and Met can serve as sources of methyl (-CH3) group. It is well understood that choline may acts as a methyl group donor, but in order to perform this function, it needs to be converted to betaine in the mitochondria (Rostagno and Pack; 1996). Many studies have examined the interrelationship between betaine and methionine to determine if betaine can spare the needs of the chick for Met. Some studies (Virtanen and Rossi, 1995) suggested that the response of broiler growth to betaine was greater than that obtained from the addition of Met, other have failed to demonstrate that the methionine content of the diet could be reduced by supplementation with betaine (El-Ganzory et al.; 2004). However, several studies suggested that addition of betaine may improve breast meat yield (McDevitt et al.; 2000). Betaine is indirectly involved in the synthesis of carnitine, which is required for transporting long chain fatty acids across the inner mitochondrial membrane for oxidation (McDevitt et al.; 2000) and therefore, may result in a leaner carcass. 
PI :( Live body weight (Kg) / feed conversion ratio) x100. Efficiency of energy utilization (EEU) was calculated according to the equation of Ali.; (1999) as follows:

EEU: (ME consumed kcal / g body weight gain).

Mortality rate $(\mathrm{MR} \%)$ was recorded daily and was calculated at the end of each age interval for each replicate throughout the experimental period. It was also calculated as a cumulative mortality.

Economic efficiency (EE)

For (EE) determination meat production management factors in all treatments were considered to be constants, and the amount of weight gains and feed consumption per treatment were calculated. Prices of feed additives and experimental diets (BET and Choline) were calculated according to the price of local market at the time of experiment. Economic efficiency was calculated as follows: [Net revenue / total cost/bird)]x100

Statistical analyses

Data from all response variables were subjected to one-way analysis of variance using General Linear Model (GLM) of SAS/STAT software (SAS Institute; 2004). Significant differences among treatment means of different variables were separated using Duncan's multiple range procedure (Duncan; 1955) at 5\% probability.

\section{RESULTS AND DISCUSSION}

Growth performance:

The effect of feeding diets added methionine was partially or totally replaced with betaine, choline or both on live body weight, weight gain, feed intake and feed conversion during the studied growth periods of broilers are presented in Table 4. The results obtained indicated that feeding the diets containing betaine or choline instead of added methionine positively affected 36-days-old live body weight (LBW) of broiler chicks compared with their control group. The highest LBW was achieved by chicks fed T10 (50\% betaine and $50 \%$ choline) and $\mathrm{T} 7(100 \%$ betaine) when compared with other dietary treatments followed by those fed the diet containing $66 \%$ betaine and $33 \%$ choline in place of added methionine and then those fed the diet containing $33 \%$ betaine and $66 \%$ choline in place of added methionine in a descending order, respectively. The same trend of response was observed in body weight gain (BWG) of chicks fed on the diets in which added methionine was replaced with betaine, choline or both during the whole experimental period compared with their control counterparts.

As indicated in Table 4, the effects of dietary treatments on feed intake $(\mathrm{FI})$ of broilers during the starter, grower and finisher phases of growth were inconclusive. While results of overall period (1-36 days), showed that the highest FI values were recorded for chicks fed T11 (33\% betaine $+33 \%$ choline $+33 \%$ methionine in place of added methionine) and the lower FI values were recorded for chicks fed T6 (66\% betaine $+33 \%$ methionine). Such slight differences among the different experimental groups of broiler chicks in FI, observed herein, seemed erratic and perhaps are not related to the effect of dietary treatments. However, dietary replacing the added methionine with betaine, choline or both led to superior means of feed conversion ratio of broilers during the three phases of growth and the whole experimental period to those attained by the control group.

Table 4. Effect of partial or complete replacing added dietary methionine with betaine, choline or both on live body weight (LBW), body weight gain (BWG), feed intake (FI), feed conversion ratio (FCR) and mortality rate $(\%)$ of broilers chicks from 0-36 days age.

\begin{tabular}{|c|c|c|c|c|c|c|c|c|c|c|c|}
\hline Items & $\begin{array}{c}\text { Tr. } 1 \\
\text { (control) }\end{array}$ & Tr. 2 & Tr. 3 & Tr. 4 & Tr. 5 & Tr. 6 & Tr.7 & Tr. 8 & Tr.9 & Tr. 10 & Tr.11 \\
\hline Initial weight & 40.00 & 40.00 & 40.00 & 40.00 & 40.00 & 40.00 & 40.00 & 40.00 & 40.00 & 40.00 & 40.00 \\
\hline $\begin{array}{l}12 \text { days old } \\
24 \text { days old } \\
36 \text { days old }\end{array}$ & $\begin{array}{c}309.79^{\mathrm{d}} \\
1077.08^{\mathrm{d}} \\
1866.67^{\mathrm{d}}\end{array}$ & $\begin{array}{c}310.83^{\mathrm{c}} \\
1078.75^{\mathrm{cd}} \\
1870.83^{\mathrm{d}}\end{array}$ & $\begin{array}{l}313 . \\
1081 . \\
1884 .\end{array}$ & $\begin{array}{c}320.42^{\mathrm{b}} \\
1096.88^{\mathrm{bc}} \\
1898.54^{\mathrm{c}}\end{array}$ & $\begin{array}{r}\text { LBW } \\
310.83^{\mathrm{c}} \\
1077.92^{\mathrm{d}} \\
1876.93^{\mathrm{cd}}\end{array}$ & $\begin{array}{l}\text { (g) at: } \\
329.79^{\mathrm{ab}} \\
1120.98^{\mathrm{b}} \\
1902.92^{\mathrm{c}}\end{array}$ & $\begin{array}{c}334.17^{\mathrm{a}} \\
1144.79^{\mathrm{a}} \\
1952.50^{\mathrm{b}}\end{array}$ & $\begin{array}{c}335.83^{\mathrm{a}} \\
1143.75^{\mathrm{a}} \\
1926.25^{\mathrm{bc}}\end{array}$ & $\begin{array}{c}314.17^{\mathrm{bc}} \\
1080.00^{\mathrm{c}} \\
1911.04^{\mathrm{bc}}\end{array}$ & $\begin{array}{c}330.83^{\mathrm{ab}} \\
1130.76^{\mathrm{ab}} \\
1980.45^{\mathrm{a}}\end{array}$ & $\begin{array}{r}311.67^{\mathrm{c}} \\
1091.02^{\mathrm{b}} \\
1897.12^{\mathrm{c}}\end{array}$ \\
\hline $\begin{array}{l}0-12 \text { days old } \\
12-24 \text { days old } \\
24-36 \text { days old } \\
0-36 \text { days old }\end{array}$ & $\begin{array}{l}269.79^{\mathrm{cd}} \\
767.29^{\mathrm{cd}} \\
789.58^{\mathrm{cd}} \\
1826.67^{\mathrm{d}}\end{array}$ & $\begin{array}{l}270.83^{\mathrm{c}} \\
767.92^{\mathrm{cd}} \\
792.08^{\mathrm{cd}} \\
1830.83^{\mathrm{d}}\end{array}$ & $\begin{array}{c}273.44^{\mathrm{bc}} \\
768.44^{\mathrm{c}} \\
802.92^{\mathrm{bc}} \\
1844.79^{\mathrm{cd}}\end{array}$ & $\begin{array}{c}280.42^{\mathrm{b}} \\
776.46^{\mathrm{c}} \\
801.67^{\mathrm{c}} \\
1858.54^{\mathrm{c}}\end{array}$ & $\begin{array}{c}\text { BWG } \\
270.83^{\mathrm{c}} \\
767.08^{\mathrm{cd}} \\
799.02^{\mathrm{c}} \\
1836.93^{\mathrm{cd}}\end{array}$ & $\begin{array}{l}\text { (g) at: } \\
289.79^{\mathrm{ab}} \\
791.19^{\mathrm{bc}} \\
781.94^{\mathrm{d}} \\
1862.92^{\mathrm{cd}}\end{array}$ & $\begin{array}{c}294.17^{\mathrm{a}} \\
810.63^{\mathrm{a}} \\
807.71^{\mathrm{bc}} \\
1912.50^{\mathrm{b}}\end{array}$ & $\begin{array}{c}295.83^{\mathrm{a}} \\
807.92^{\mathrm{ab}} \\
782.50^{\mathrm{d}} \\
1886.25^{\mathrm{bc}}\end{array}$ & $\begin{array}{c}274.17^{\mathrm{bc}} \\
765.83^{\mathrm{d}} \\
831.04^{\mathrm{b}} \\
1871.04^{\mathrm{bc}}\end{array}$ & $\begin{array}{c}290.83^{\mathrm{ab}} \\
799.92^{\mathrm{b}} \\
849.70^{\mathrm{a}} \\
1940.45^{\mathrm{a}}\end{array}$ & $\begin{array}{l}271.67^{\mathrm{c}} \\
779.36^{\mathrm{c}} \\
806.10^{\mathrm{bc}} \\
1857.12^{\mathrm{c}}\end{array}$ \\
\hline $\begin{array}{l}\text { old } \\
\text { old } \\
\text { old } \\
\text { old }\end{array}$ & $\begin{array}{l}370.12^{\mathrm{bc}} \\
1262.50^{\mathrm{b}} \\
11435.00^{\mathrm{ab}} \\
3067.92^{\mathrm{ab}} \\
\end{array}$ & & $\begin{array}{l}368.7 \\
1228 . \\
1431 . \\
3029 .\end{array}$ & $\begin{array}{r}367.08 \\
1215.8 \\
1413.7 \\
2996.6 \\
\end{array}$ & $\begin{array}{r}\mathrm{FC}(\mathrm{g} \\
369.58^{\mathrm{c}} \\
\mathrm{d} 1236.25^{\mathrm{c}} \\
1398.75^{\mathrm{cd}} \\
3004.58^{\mathrm{bc}}\end{array}$ & $\begin{array}{l}\text { g) at: } \\
375.83^{\text {ab }} \\
1201.04^{\mathrm{d}} \\
1377.92^{\mathrm{d}} \\
2954.79^{\mathrm{d}}\end{array}$ & $\begin{array}{l}376.25^{\mathrm{ab}} \\
1200.42^{\mathrm{d}} \\
1384.58^{\mathrm{d}} \\
2961.25^{\mathrm{d}}\end{array}$ & $\begin{array}{c}378.96^{\mathrm{a}} \\
1202.29^{\mathrm{d}} \\
1392.29^{\mathrm{cd}} \\
2973.54^{\mathrm{cd}} \\
\end{array}$ & $\begin{array}{l}370.83^{\mathrm{bc}} \\
1199.17^{\mathrm{d}} \\
1451.25^{\mathrm{a}} \\
3021.25^{\mathrm{b}}\end{array}$ & $\begin{array}{c}376.67^{\mathrm{ab}} \\
1247.86^{\mathrm{bc}} \\
1449.20^{\mathrm{a}} \\
3073.73^{\mathrm{ab}} \\
\end{array}$ & $\begin{array}{c}366.88^{\mathrm{d}} \\
1275.19^{\mathrm{a}} \\
1436.59^{\mathrm{ab}} \\
3078.66^{\mathrm{a}}\end{array}$ \\
\hline $\begin{array}{l}\text { old } \\
\text { s old } \\
\text { s old } \\
\text { old }\end{array}$ & $\begin{array}{l}1.38^{\mathrm{a}} \\
1.65^{\mathrm{a}} \\
1.82^{\mathrm{a}} \\
1.68^{\mathrm{a}}\end{array}$ & $\begin{array}{l}1.37^{\mathrm{ab}} \\
1.63^{\mathrm{ab}} \\
1.81^{\mathrm{a}} \\
1.67^{\mathrm{a}}\end{array}$ & $\begin{array}{l}1.35^{\mathrm{b}} \\
1.60^{\mathrm{b}} \\
1.78^{\mathrm{ab}} \\
1.64^{\mathrm{b}}\end{array}$ & $\begin{array}{l}1.31^{\mathrm{bc}} \\
1.57^{\mathrm{bc}} \\
1.76^{\mathrm{b}} \\
1.61^{\mathrm{c}}\end{array}$ & $\begin{array}{l}(\mathrm{FCF} \\
1.37^{\mathrm{ab}} \\
1.61^{\mathrm{b}} \\
1.75^{\mathrm{bc}} \\
1.64^{\mathrm{b}}\end{array}$ & $\begin{array}{l}\text { at: } \\
1.30^{\mathrm{bc}} \\
1.52^{\mathrm{cd}} \\
1.76^{\mathrm{b}} \\
1.59^{\mathrm{c}}\end{array}$ & $\begin{array}{l}1.28^{\mathrm{d}} \\
1.48^{\mathrm{d}} \\
1.72^{\mathrm{c}} \\
1.55^{\mathrm{d}}\end{array}$ & $\begin{array}{l}1.28^{\mathrm{d}} \\
1.49^{\mathrm{d}} \\
1.78^{\mathrm{ab}} \\
1.58^{\mathrm{cd}}\end{array}$ & $\begin{array}{l}1.35^{\mathrm{b}} \\
1.57^{\mathrm{bc}} \\
1.75^{\mathrm{bc}} \\
1.61^{\mathrm{c}}\end{array}$ & $\begin{array}{l}1.30 \mathrm{~b}^{\mathrm{c}} \\
1.56^{\mathrm{c}} \\
1.71^{\mathrm{d}} \\
1.58^{\mathrm{cd}}\end{array}$ & $\begin{array}{l}1.35^{\mathrm{ab}} \\
1.64^{\mathrm{a}} \\
1.79^{\mathrm{ab}} \\
1.66^{\mathrm{ab}}\end{array}$ \\
\hline-36 day & $2.85^{\mathrm{a}}$ & $2.70^{\mathrm{b}}$ & $2.20^{\mathrm{cd}}$ & $2.00^{\mathrm{cd}}$ & $\begin{array}{l}\text { Mortality r } \\
2.40^{\mathrm{c}}\end{array}$ & $\begin{array}{c}\text { ate }(\%) \text { at } \\
1.92^{\mathrm{cd}}\end{array}$ & $1.76^{\mathrm{d}}$ & $1.80^{\mathrm{d}}$ & $1.92^{\mathrm{cd}}$ & $1.76^{\mathrm{d}}$ & $2.20^{\mathrm{cd}}$ \\
\hline
\end{tabular}

a, b, $c$ and $d$ Means at the same row with different superscripts differ significantly $(P<0.05)$ different.

It is evident that supplementation with betaine to broiler diets produced a positive effect on body weight gain and feed conversion ratio when compared with those of the control group. However, (Dorra et al:; 2012) indicated that betaine supplementation increased feed intake of growing toms, which is in contrast to the present results. In accordance with the present results, (Tolba et al:; 2007) showed that dietary supplemental betaine improved feed conversion and live body weight of fayoum laying hens as compared to the respective control. (Honarbakhsh et al.; 2007) stated that betaine supplementation increased body weight and improved feed conversion ratio of broiler chicks in grower and finisher periods. The aforementioned authors have hypothesized that betaine as an osmolyte that could 
improve intestinal structure and function to increase growth performance. Generally, a positive effect of betaine on performance of broilers was reported by others (Hamidi et al.; 2010) and ducks (Wang et al.; 2004).

Similar results were reported by several authors. In this respect, betaine supplementation $(800 \mathrm{mg} / \mathrm{kg}$ diet) enhanced growth at 21 days and feed conversion efficiency at 42 days of age in broilers fed a diet containing $15 \mathrm{~g} \mathrm{Met} / \mathrm{kg}$ CP (Rama Rao et al.; (2011). Moreover, betaine significantly $(\mathrm{P} \leq 0.05)$ improved body weight and feed conversion of Matrouh chickens at a level of $1 \mathrm{~g} / \mathrm{kg}$ diet (Ezzat et al.; 2011).

Also, (Enting et al.; 2007) showed that the addition of 1 and $2 \mathrm{~g} / \mathrm{kg}$ betaine to the feed improved feed conversion ratio of broiler chickens from 0 to 14 days of age and body weight at 40 days of age. Moreover, (Honarbakhsh et al.; 2007) evaluated the effects of different exogenous betaine levels $(0,0.075,0.150$ and $0.225 \%)$ on growth performance of male broiler chicks (Ross). They observed that betaine supplementation increased body weight and improved feed conversion ratio in grower and finisher periods $(\mathrm{P} \leq 0.01)$.

Also, (Jahanian and Rahmani00; 2008) found that no effect on feed intake dietary betaine inclusion of broiler. These findings indicate that dietary betaine inclusion instead of choline had little benefit in terms of parameters performance. (El-Husseiny et al.; 2007) estimated the effect of methionine levels $(0.33$ and $0.45 \%$ ) with betaine on broiler performance, revealing that B.W.G and F.C.E were significantly increased with increasing betaine levels up to $0.75 \mathrm{~g} / \mathrm{kg}$ diet.

Mortality\%:

The mortality rates as of broiler chicks affected by dietary treatments are presented in Table 4. It could be noticed that all birds appeared health and total mortality rates were within the normal range among treatments and ranged between $1.76-2.85 \%$ (birds), indicating that mortality rates were not related to the effect of dietary treatments. The obtained means of mortality rates are lower than those previously reported by (Tollba et al.; 2004), who found that mortality rate was $5 \%$ when they reared broiler chicks in normal conditions $\left(24^{\circ} \mathrm{C}\right)$.

In respect of dietary treatments, the results showed that birds fed the control ration recorded, the highest mortality rate. Among all dietary treatments studied, inclusion of betaine alone or $50 \%$ betaine and $50 \%$ choline instead of added dietary methionine had lower mortality rates when compared to those of other treatments. It is of interest to note that replacement of methionine with choline produced intermediate mortality rates.

Efficiency of protein (PER) and energy utilization (EEU) and performance index (PI):

The effect of replacing added dietary methionine with betaine, choline or both on PER, EEU and PI of broiler chicks throughout the entire experimental periods are summarized in Table 5. During starter period (0-12 days old) the results showed that complete replacement of methionine with betaine or with betaine replacement at a level of $100 \%$ and $66 \%$ betaine and $33 \%$ choline led to a significant increase in PER $(\mathrm{p}<0.05)$ values than other treatments and the control one. While through the grower period (12-24 days old), the highest PER values were recorded for chicks fed T7 (100\% betaine), T8 (66\% betaine plus 33\% choline) and T10 (50\% betaine plus 50\% choline) when compared with other dietary treatments. Results of the finisher period (24 to 36 days old) showed similar results as starter period. Overall period (0-36 days old) birds fed $100 \%$ betaine in place of added dietary methionine achieved significantly higher PER $(\mathrm{P}<0.05)$ values than other treatments while control ration had the lowest value.

Table 5. Effect of partial or replacing added dietary methionine with betaine, choline or both on protein efficiency ratio (PER), efficiency of energy utilization (EEU) and performance index (PI) of broiler chicks from 0-36 days of ago

\begin{tabular}{|c|c|c|c|c|c|c|c|c|c|c|c|}
\hline Items & 1 (control) & Tr. 2 & Tr. 3 & Tr. 4 & Tr. 5 & Tr. 6 & Tr.7 & Tr. 8 & Tr. 9 & Tr. 10 & Tr. 11 \\
\hline & & & $\begin{array}{l}0.307^{\mathrm{c}} \\
0.343^{\mathrm{bd}} \\
0.358^{\mathrm{dc}} \\
0.344^{\mathrm{bc}}\end{array}$ & $\begin{array}{c}\text { otein effic } \\
0.298^{\mathrm{bc}} \\
0.336^{\mathrm{b}} \\
0.354^{\mathrm{bd}} \\
0.338^{\mathrm{b}}\end{array}$ & $\begin{array}{c}\text { iency rat } \\
0.311^{\text {cd }} \\
0.346^{\mathrm{d}} \\
0.351^{\mathrm{b}} \\
0.343^{\mathrm{b}}\end{array}$ & $\begin{array}{c}\text { (PER) } \\
0.295^{\mathrm{b}} \\
0.325^{\mathrm{ab}} \\
0.354^{\mathrm{bd}} \\
0.333^{\mathrm{b}}\end{array}$ & $\begin{array}{l}\text { at: } \\
0.291^{\mathrm{a}} \\
0.317^{\mathrm{a}} \\
0.344^{\mathrm{a}} \\
0.325^{\mathrm{a}}\end{array}$ & & & $\begin{array}{c}0.295^{\mathrm{b}} \\
0.334^{\mathrm{b}} \\
0.342^{\mathrm{a}} \\
0.332^{\mathrm{ab}}\end{array}$ & $\begin{array}{c}0.307^{\mathrm{c}} \\
0.351^{\mathrm{dc}} \\
0.358^{\mathrm{d}} \\
0.347^{\mathrm{c}}\end{array}$ \\
\hline & & & $\begin{array}{l}\text { Efficier } \\
4.08^{\mathrm{b}} \\
4.97^{\mathrm{bc}} \\
5.70^{\mathrm{b}} \\
5.11^{\mathrm{bc}}\end{array}$ & $\begin{array}{c}\text { ncy of en } \\
3.46^{\mathrm{bd}} \\
4.87^{\mathrm{c}} \\
5.64^{\mathrm{bc}} \\
5.02^{\mathrm{c}}\end{array}$ & $\begin{array}{c}\text { ergy utili } \\
4.13^{\mathrm{ab}} \\
5.01^{\mathrm{b}} \\
5.60^{\mathrm{c}} \\
5.09^{\mathrm{bc}}\end{array}$ & $\begin{array}{c}\text { zation (E) } \\
3.92^{\mathrm{d}} \\
4.72^{\mathrm{cd}} \\
5.64^{\mathrm{bc}} \\
4.99^{\mathrm{c}}\end{array}$ & $\begin{array}{l}\text { EU) at: } \\
3.87^{\mathrm{c}} \\
4.60^{\mathrm{d}} \\
5.48^{\mathrm{cd}} \\
4.82^{\mathrm{d}}\end{array}$ & & & & $\begin{array}{l}4.09^{\mathrm{b}} \\
5.08^{\mathrm{ab}} \\
5.70^{\mathrm{b}} \\
5.16^{\mathrm{b}}\end{array}$ \\
\hline & $\begin{array}{r}22.51^{\mathrm{d}} \\
65.28^{\mathrm{d}} \\
111.13^{\mathrm{d}} \\
\end{array}$ & $\begin{array}{c}22.68^{\mathrm{cd}} \\
66.18^{\mathrm{d}} \\
112.21^{\mathrm{cd}}\end{array}$ & $\begin{array}{l}23.24^{\mathrm{bc}} \\
67.60^{\mathrm{cd}} \\
114.78^{\mathrm{c}}\end{array}$ & $\begin{array}{c}\text { Performa } \\
24.48^{\mathrm{b}} \\
70.05^{\mathrm{c}} \\
117.75^{\mathrm{bc}}\end{array}$ & $\begin{array}{c}\text { ince inde } \\
22.67^{\mathrm{cd}} \\
66.87^{\mathrm{d}} \\
114.75^{\mathrm{c}}\end{array}$ & $\begin{array}{l}\mathrm{x}(\mathrm{PI}) \mathrm{at}: \\
25.43^{\mathrm{ab}} \\
73.82^{\mathrm{bc}} \\
117.49^{\mathrm{bc}}\end{array}$ & $\begin{array}{c}26.13^{\mathrm{a}} \\
77.30^{\mathrm{a}} \\
126.10^{\mathrm{a}}\end{array}$ & $\begin{array}{c}26.21^{\mathrm{a}} \\
76.84^{\mathrm{b}} \\
122.19^{\mathrm{b}}\end{array}$ & $\begin{array}{l}23.22^{\mathrm{bc}} \\
68.97^{\mathrm{cd}} \\
\mathrm{b}^{\mathrm{bc}}\end{array}$ & $\begin{array}{c}25.55^{\mathrm{ab}} \\
72.49^{\mathrm{bc}} \\
125.00^{\mathrm{ab}}\end{array}$ & $\begin{array}{c}23.08^{\mathrm{c}} \\
66.54^{\mathrm{cd}} \\
114.46^{\mathrm{cd}}\end{array}$ \\
\hline
\end{tabular}
$a, b$, c and $d$ Means at the same row with different superscripts are differ significantly $(P<0.05)$ different.

During the overall period (0-36 days old), replacement inclusion of betaine to replace $100 \%$ of added methionine in broiler diet result significantly $(\mathrm{P}<0.05)$ the best EEU value (4.82) as compared to the control group (5.22), this finding positively corresponds with the highest BWG of $1912.5 \mathrm{~g} /$ bird period for treatment seven and lowest BWG of $1826.7 \mathrm{~g}$ /bird period of the control group, respectively. During all examined periods and the whole experimental period in comparison to all dietary treatments the EEU corresponding values ranged from 4.82-5.22 confirming that the control group had significantly lower
EEU value $(\mathrm{P}<0.05)$ which corresponds with the lowest BWG. This agree with the results observed by (ElShinnawy; 2015), who reported that EEU of broiler chicks was positively affected by dietary supplementation with graded levels of betaine during all phases of growth compared with those of their control.

Dietary inclusion of $100 \%$ betaine instead of added methionine in broiler diets resulted insignificantly higher PI value $(\mathrm{P}<0.05)$ through starter period $(0-12$ days of age $)$ till the end of the experiment, followed by treatment $10(50 \%$ betaine $+50 \%$ choline) and treatment $8(66 \%$ betaine and 
$33 \%$ choline). It is worth to note that the control group recorded the lowest PI value during all experiment periods. Among all dietary treatments studied treatment $4(100 \%$ choline), treatment 6 ( $66 \%$ betaine $+33 \%$ choline $)$ showed intermediate values, when compared to those of other dietary treatments.

Economic efficiency:

The profitability of replacing added dietary methionine with betaine, choline or both in starting, growing and finishing diets of broiler depends on the cost of these ingredients and their effect on growth performance.

Data presented in Table 6, show that the lowest cost $/ \mathrm{kg}$ body weight (11.96 LE) was observed with chicks fed diets in which betaine completely replaced the added methionine, followed by those fed treatment eight $(66 \%$ betaine and $33 \%$ choline) and treatment $10(50 \%$ betaine and $50 \%$ choline), while the highest (12.91 LE) was recorded with control group (zero replacement). This may be due to the fact that inclusion of betaine and/or choline in the diets scored better, B.W, W.G and F.C.R. beside the lower prices of these ingredients when compared with methionine.

These results reflected the highest economic efficiency value for T7 (151\%) followed by T8 (147\%) and T10 (146\%). However, those in the control group showed the lowest value of economic efficiency $(132 \%)$. The relative increases in economic efficiency of broiler due to adding betaine or betaine and choline as partial or complete substitutes for methionine ranged between 2.0 and $14.0 \%$ these improvements could be attributed to the improved body weight gain, feed conversion and low prices of betaine and choline compared with methionine.

In conclusion, partial or complete replacing added dietary methionine with different levels of betaine, choline or both had positive effect on final B.W, B.W.G, F.C.R and E.E of broiler chicks. Further experimentation on the subject may be carried out to establish the fact that added dietary methionine can be partly or totally provided by other available methyl donors.

Table 6. Effect of partial or complete replacing added dietary methionine with betaine, choline or both on economic efficiency of broiler production from 0-36 days old

\begin{tabular}{|c|c|c|c|c|c|c|c|c|c|c|c|}
\hline Items & $\begin{array}{c}\text { Tr. 1 } \\
\text { (control) }\end{array}$ & Tr. 2 & Tr. 3 & Tr. 4 & Tr. 5 & Tr. 6 & Tr.7 & Tr. 8 & Tr.9 & Tr. 10 & Tr.11 \\
\hline Fixed Cost (L & $a^{a} 3.00$ & 3.00 & 3.00 & 3.00 & 3.00 & 3.00 & 3.00 & 3.00 & 3.00 & 3.00 & 3.00 \\
\hline & & & & & & & & & & & \\
\hline & $370.12^{\mathrm{bc}}$ & $27125^{\mathrm{b}}$ & $368.75^{\mathrm{bc}}$ & $367.08^{\mathrm{cd}}$ & & & & & & & \\
\hline & & & & & & & $2^{d}$ & & & & \\
\hline & $35.00^{\mathrm{ab}}$ & & & & & & & & & & \\
\hline & & & & & & & & & & & \\
\hline & $2.512^{\mathrm{bc}}$ & $.519^{\mathrm{b}}$ & $2.50^{\mathrm{bc}}$ & $2.489^{\mathrm{cd}}$ & $2.508^{\mathrm{c}}$ & $2.550^{\mathrm{ab}}$ & $2.552^{\mathrm{ab}}$ & $2.570^{\mathrm{a}}$ & $2.515^{\mathrm{bc}}$ & $2.554^{\mathrm{ab}}$ & $2.489^{\mathrm{d}}$ \\
\hline & $718^{\mathrm{b}}$ & $b^{b c}$ & $8.481^{c}$ & & $8.534^{c}$ & 8.2 & & & & $8.611^{b c}$ & $8.801^{\mathrm{a}}$ \\
\hline & $9.863^{\mathrm{ab}}$ & $9.845^{\mathrm{b}}$ & $9.838^{b}$ & $9.712^{c}$ & $9.612^{\mathrm{cd}}$ & $9.469^{d}$ & $9.513^{\mathrm{d}}$ & 9.564 & $9.969^{\mathrm{a}}$ & $\begin{array}{l}0.011 \\
9.955^{\mathrm{a}}\end{array}$ & $9.872^{\mathrm{ab}}$ \\
\hline & $21.093^{\mathrm{b}}$ & $20.976^{\mathrm{bc}}$ & $20.820^{\mathrm{bc}}$ & $20.591^{\mathrm{cd}}$ & $20.654^{c}$ & $20.309^{\mathrm{d}}$ & $20.350^{\mathrm{d}}$ & & $20.759^{c}$ & $21.120^{\mathrm{b}}$ & $21.162^{\mathrm{a}}$ \\
\hline & $24.093^{\mathrm{b}}$ & $23.976^{\mathrm{bc}}$ & $23.820^{\mathrm{bc}}$ & $23.591^{\mathrm{cd}}$ & $23.654^{\mathrm{c}}$ & $23.309^{\mathrm{d}}$ & $23.350^{d}$ & 23.4 & & $24.130^{\mathrm{b}}$ & \\
\hline & & $1.870^{\mathrm{d}}$ & $1.884^{\mathrm{cd}}$ & $1.898^{\mathrm{c}}$ & & $1.902^{\mathrm{c}}$ & $1.952^{\mathrm{b}}$ & & 1.9 & & $97^{\mathrm{c}}$ \\
\hline & $12001^{a}$ & 1.01 & 10 & & 12.6 & $12.26^{\mathrm{cd}}$ & 110 & & & & b \\
\hline & & & & 56.94 & 56.2 & 57.0 & $\begin{array}{l}11 \\
58 .\end{array}$ & & & & \\
\hline e (LE)e & $87^{\mathrm{d}}$ & 32.1 & $32.700^{\mathrm{c}}$ & & 32. & 33.7 & $210^{\mathrm{a}}$ & $34.349^{\mathrm{ab}}$ & & $35.270^{\mathrm{a}}$ & \\
\hline & & & & & & & & & & & \\
\hline Relative $\mathrm{EE}^{\mathrm{h}}$ & $100.00^{\mathrm{d}}$ & $102.00^{\mathrm{cd}}$ & $104.00^{\mathrm{c}}$ & $107.00^{b c}$ & $105.00^{\mathrm{c}}$ & $108.00^{\mathrm{b}}$ & $114.00^{\mathrm{a}}$ & $111.00^{\mathrm{ab}}$ & $107.00^{\mathrm{bc}}$ & $111.00^{\mathrm{ab}}$ & $103.00^{\mathrm{cc}}$ \\
\hline
\end{tabular}

Where: $\mathrm{c}=(\mathrm{a}+\mathrm{b}) \mathrm{e}=(\mathrm{d}-\mathrm{c}) \mathrm{f}=(\mathrm{e} / \mathrm{c}) \quad \mathrm{h}=(\mathrm{EE}$ of treatment/EE of control $) \times 100$. Free market prices (LE/ton) for feed ingredients used in formulating the experimental ration in the year (2017),

$a, b, c$ and $d$ Means at the same row with different superscripts differ significantly $(\mathrm{P}<0.05)$ different.

\section{REFERENCES}

Ali, Mervat A. (1999). Effect of probiotics addition to broiler rations on performance and some blood constituents. Egypt Poult. Sci. J.; 19: 161-177.

Dorra, Tork, I.; Samya, E. Ibrahim and Sh. M. Zayed (2012). Effect of dietary betaine supplementation on growth performance and carcass traits of growing turkey. J. Anim. Poultry Prod.; Mansoura Univ.; 3(7): 365-377.

Duncan, D. B. (1955). Multiple range and multiple F-tests. Biometrics 11: 1-42.

El-Ganzory, E.H.; R.A. Hassan and Kout El-Kloub M.E. Moustafa (2004). Effect of betaine and/or sodium sulphate supplementation as a substitute for methionine in chick diets. Egypt. Poult. Sci.; 24:823843.

El-Husseiny, O. M.; M. A. Abo-El-Ella; M. O. AbdElsamee and M. M. Abd-Elfattah (2007). Response of broilers performance to dietary betaine and folic acid at different methionine levels. Int. J. of Poult. Sci. 6(7): 515-523.
El-Shinnawy, A. M (2015). Effect of betaine supplementation to methionine adequate diet on growth performance, carcass characteristics, some blood parameters and economic efficiency of broilers J. Anim. Poultry Prod.; Mansoura Univ.; 6 (1):27-41.

Enting, H.; J. Eissen; J. De Los Mozos; A. G. Alamo and P. P. Ayala (2007). TNI Betaine improves broiler chicken performance and carcass quality under heat stress conditions. World's Poult. Sci. Association, Proceedings of the 16th European Symposium on Poultry Nutrition, Strasbourg, France, 26-30 August, 2007. 297-300.

Esteve-Garcia, E. and S. Mack (2000). The effect of DLmethionine and betaine on growth performance and carcass characteristics in broilers. Animal Feed Science and Technology, 87(1/2): 85-93.

Ezzat, W.; M. S.Shoeib; S. M. M. Mousa; A. M. A. Bealish and Z. A. Ibrahiem (2011). Impact of betaine, vitamin $\mathrm{C}$ and folic acid supplementations to the diet on productive and reproductive performance of Matrouh poultry strain under Egyptian summer condition. Egypt. Poult. Sci., 31(2): 521-537. 
Gao, S.L.; C.H. Shao; Y.E. Li and X.Y. Sun, (2006). Effects of different amount of betaine instead of methionine on broilers. Hubei J. Anim. Vet. Sci.; 1: 10-11.

Hamidi, H.; R. Jahanian and J. Pourreza (2010). Effect of dietary betaine on performance, immunocompetence and gut contents osmolarity of broilers challenged with a mixed coccidial infection. Asian J. Anim. Vet. Adv, 5 (3): 193-201.

Honarbakhsh, S.; M. Zaghari and M. Shivazad (2007). Can exogenous betaine be an effective osmolyte in broiler chicks under water salinity stress? AsianAust. J. Anim. Sci.; 20(11): 1729-1737.

Jahanian, R. and H. R. Rahmani (2008). The effect of dietary fat level on the response of broiler chicks to betaine and choline supplements. J. Biol. Sci.; 8(2): 362-367.

Matthews, J.O. and L.L. Southern, (2000). The effect of dietary betaine in Eimeria acervulina-infected chicks. Poult. Sci.; 79: 60-65.

McDevitt, R.M.; S. Mack and I.R. Wallis (2000). Can betaine partially replace or enhance the effect of methionine by improving broiler growth and carcase characteristics? Br. Poult. Sci.; 41:463-480.

McKeever, M.P.; D.G. Weir; A. Molloy and J.M. Scott, (1991). Betaine-homocysteine methyltransferase: organ distribution in man, pig and rat and subcellular distribution in the rat. Clin. Sci.; (London, England) 81: 551-556.

North, M.O. (1984). Commercial Chicken Production Manual. 3rd Ed. AVI.; Publishing Company. I.N.C. Westport Connecticut, USA.

NRC, National Research Council (1994). Nutrient Requirements of Poultry. 9th rev. ed.; National Academy Press, Washington, DC.

Park, J.H.; C.W. Kang and K.S. Ryu (2006). Effects of feeding betaine on performance and blood hormone in laying hens. Kor. J. Poult. Sci.; 33: 323-328.
Persia, M.E.; C.M. Parsons; M. Schang and J. Azcona (2003). Nutritional evaluation of dried tomato seeds. Poultry Science, 82 (1) :141-146.

Petronine, P.G.; E.M. De angelis; P. Broghetti A.F. and K.P. Wheeler (1992). Modulation by betaine of cellular responses to osmotic stress. J. Biochem.; 282 : 69-73.

Rama Rao, S. V.; M. V. L. N. Raju; A. K. Panda; P. Saharia and G. S. Sunder (2011). Effect of supplementing betaine on performance, carcass traits and immune responses in broiler chicken fed diets containing different concentrations of methionine. Asian-Aust. J. Anim. Sci.; 24(5): 662- 669.

Rostagno, H. S. and M. Pack (1996). Can betaine replace supplemental Dl-methionine in broiler diets? J. Appl. Poult. Res.; 5 : 150-154.

SAS Institute (2004). SAS /STAT User's Guide. Release 9.1. SAS inst. Inc.; Cary NC.; USA.

Tollba, A.A.H.; M.M. Sabry and S.M.M. Abuzead (2004). Effect of microbial probiotics on performance of broiler chicks under normal or heat stress conditions: 1- Lactobacillus or Pediococcus. Egypt. Poultry Sci.; 24(2): 351-367.

Tollba, A.A.H.; S.A.M. Shabaan and A.Z. Wagdy (2007). Improvement of Fayoumi laying hens performance under hot climate conditions: 2 - Betaine, folic acid and choline. Egypt. Poult. Sci. J. 27(1): 21-35.

Virtanen, E. and L. Rosi (1995). Effects of betaine on methionine requirement of broilers under various environmental conditions. In : proc. Australian Poultry Science Symposium, Sydney, Australia, pp. 88-92.

Wang, Y. Z.; Z. R. Xu and J. Feng (2004). The effect of betaine and DLmethionine on growth performance and carcass characteristics in meat ducks. Anim. Feed Sci. Techn.; 116(1/2): 151-159.

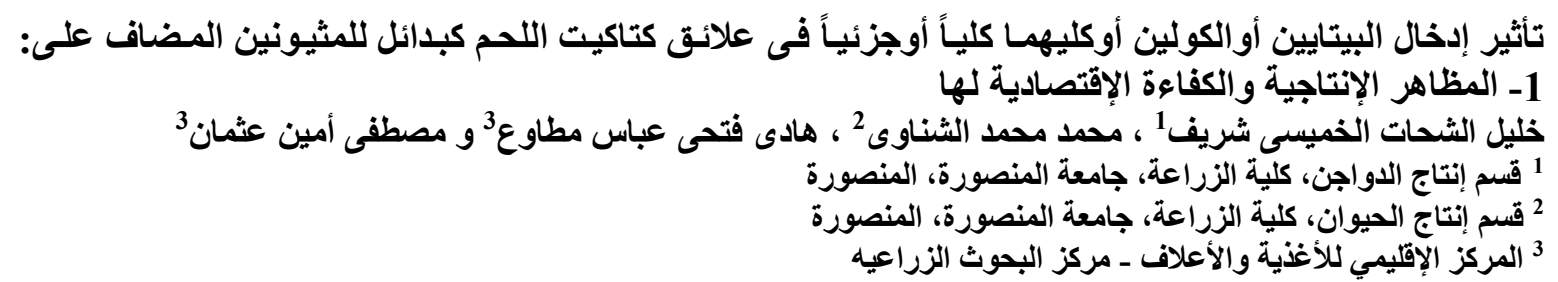

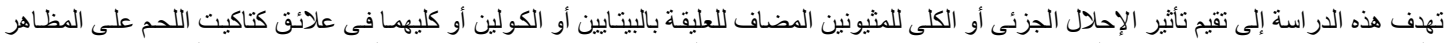

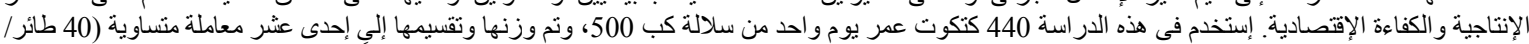

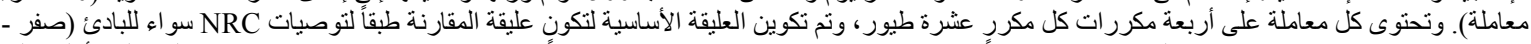

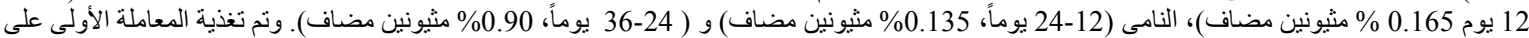

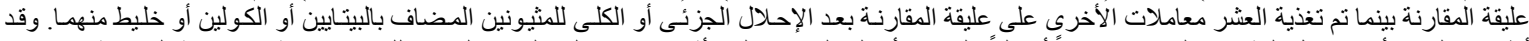

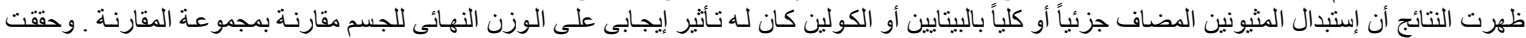

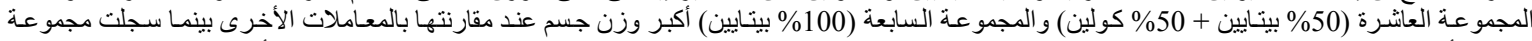

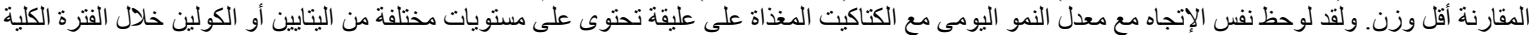

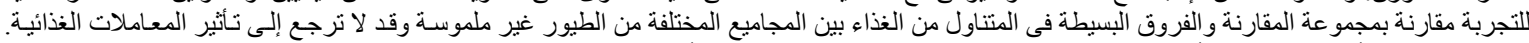

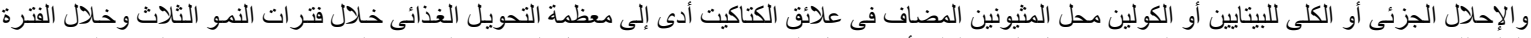

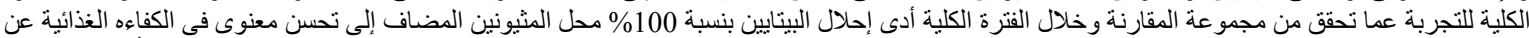

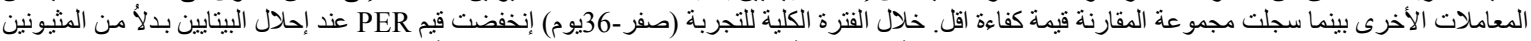

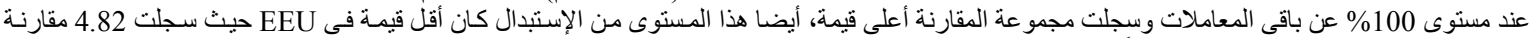

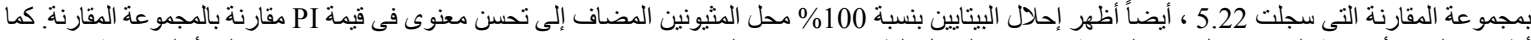

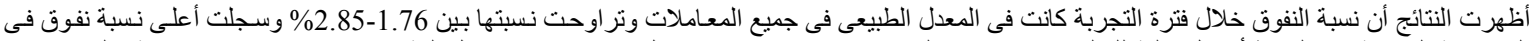

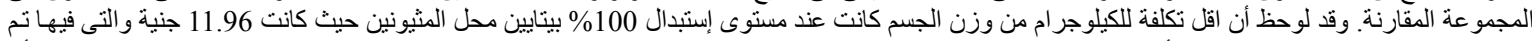

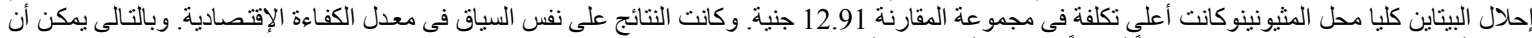

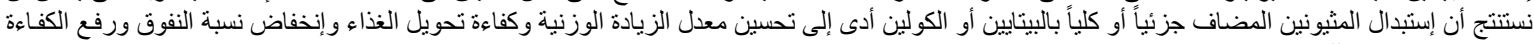
الإقتصادية الإنتاجية للكتاكيت النتين 